\title{
Efficiency of underground retention systems and reduction of urban floods in Tepic, Mexico
}

\author{
Eficiencia de sistemas subterráneos de retención y reducción de inundaciones urbanas en \\ Tepic, México
}

\author{
Germán Antonio Ramírez-Quele (1) ${ }^{1}$, Mario Guadalupe González-Pérez $\mathbb{1}^{2 *}$, Fernando Flores-Vilchez (103) ${ }^{3}$, \\ Yefer Asprilla-Lara $\mathbb{1}^{4}$, Jesús Rodríguez-Rodríguez (102 ${ }^{2}$ \\ ${ }^{1}$ Departamento de Ingenierías, Facultad de Ingenieria Civil, Universidad Autónoma de Guadalajara. Av. Patria 1201. C. P. \\ 45129. Zapopan, México. \\ ${ }^{2}$ Centro Universitario de Tonalá, Departamento de estudios del agua y la energia, Universidad de Guadalajara. Av. Nuevo \\ Periférico No. 555 Ejido San José Tateposco. C. P. 45425. Tonalá, México. \\ ${ }^{3}$ Departamento de Ciencias Básicas e Ingeniería, Universidad Autónoma de Nayarit. Ciudad de la Cultura Amado Nervo. \\ C. P. 63155. Tepic, México. \\ ${ }_{4}^{4}$ Facultad del Medio Ambiente y Recursos Naturales, Universidad Distrital Francisco José de Caldas. Carrera 7 \# 40B - \\ 53. C. P. 11021 . Bogotá, Colombia.
}

\section{CITE THIS ARTICLE AS:}

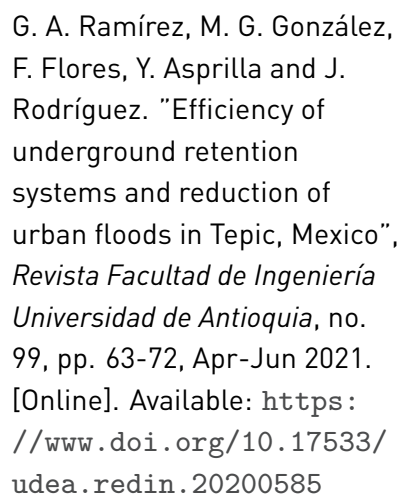

G. A. Ramírez, M. G. González, F. Flores, Y. Asprilla and J. Rodríguez. "Efficiency of underground retention systems and reduction of urban floods in Tepic, Mexico", Revista Facultad de Ingeniería Universidad de Antioquia, no. 99, pp. 63-72, Apr-Jun 2021. [Online]. Available: https: //www.doi.org/10.17533/ udea.redin. 20200585

\section{ARTICLE INFO:}

Received: February 11, 2020 Accepted: June 03, 2020

Available online: June 03, 2020

\section{KEYWORDS:}

Control; flow; rains; SUDS; urbanization

Control; caudal; precipitaciones; SUDS; urbanización
ABSTRACT: Many cities in Mexico experience recurrent floods, caused by changes in land use, the modification of surface and land runoff, the artificialization of areas initially intended for infiltration and recharge of groundwater and, in general, the insufficiency and deficiency of the local networks of urban drainage, incapable to evacuate the annual surpluses of precipitation. In this sense, the objective of this study evaluates the efficiency of an underground system of retention of rainwater in one of the main avenues of the city of Tepic, Mexico: Avenida Tecnologico. To this end, an analysis of the thematic contents and on-site inspection assisted by geographic information systems is carried out. Based on the systems approach and the logic of a qualitative model, it is concluded that the capacity of urban storm water networks for water evacuation is exceeded dimensionally. Also, it can be observed that retention systems can mitigate the urban entropy generated by the floods.

RESUMEN: Diversas ciudades de México han venido presentando recurrentes inundaciones ocasionadas por cambios en los usos del suelo, modificación de los escurrimientos superficiales y subterráneos, artificialización de las zonas destinadas inicialmente para la infiltración y recarga freática, y en general, insuficiencia y deficiencia de las redes locales de drenaje urbano que se vuelven incapaces de evacuar los excedentes anuales de precipitación. En este sentido, el objetivo de este estudio evalúa la eficiencia de un sistema subterráneo de detención de agua pluvial en una de las principales avenidas de la ciudad de Tepic, México: la Avenida Tecnológico. Para ello, se realiza un análisis de contenidos temáticos e inspección in situ auxiliados por sistemas de información geográfica, cuyos resultados muestran, desde un enfoque sistémico y la lógica de un modelo cualitativo, que la capacidad de las redes pluviales urbanas de evacuación de agua pluvial en el centro urbano está dimensionalmente rebasada y que la alternativa de sistemas de retención-detención pueden mitigar la entropía urbana generada por las inundaciones.

\section{Introduction}

Urban-housing growth has often irrevocably altered the structure and functioning of the biotic and abiotic

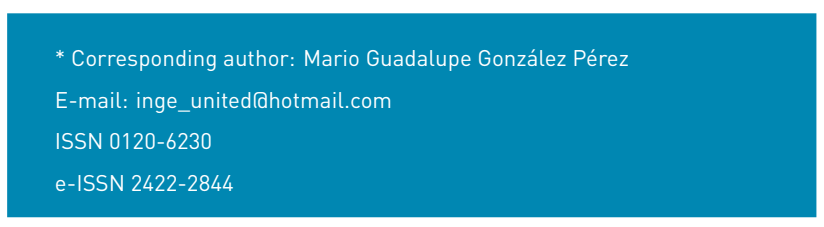

subsystems respectively. This has directly and indirectly diminished "the hydrological response of the basins, increasing the occurrence and magnitude of flooding" [1]. In urban environments, for example, rainwater drainage systems designed to evacuate water produced by precipitation contain a common denominator related to the insufficiency of hydraulic operation [2]. As expressed, "when urban expansion and land use planning are not carried out together, the anarchic growth of impermeable 
surfaces occurs" [3]. Also, it can observed, that it inevitably ends up in flooding incidents.

Indeed, a natural process of infiltration occurs, and some of this infiltrated water constitutes the flow of rivers and streams or, in some other cases, feeds the aquifers. Nevertheless, surpluses are generally accumulated in the lower areas, where they complicate evacuation and put the urban dweller at risk. In these areas, the level of danger depends on the magnitude, occurrence and correlation of the natural phenomena involved [4] Furthermore, if the set of processes that accompany the urbanization disrupts the cycle and the necessary compensations are not made, considerable negative impacts of difficult mitigation can be generated [5].

In this context, the absence of rainwater retention systems can cause urban problems. On the one hand, the use of rigid and flexible road surfaces is increasingly being used to prevent leaks to the subsoil, resulting in an inflow volume of water that exceeds the ability of the drainage network to conduct the surpluses. It has been reported in the open literature that holding ponds not only reduce peak flows, but also decrease the kinetic energy of runoff, and consequently minimize erosion and the ability to transport contaminants [6]. These structures are similar to infiltration deposits, but with greater depth, due to the need to store large volumes and then be introduced gradually to drainage [7].

The first underground drainage network was built in Paris, France in the XIX century, and it has become an extremely important system for collecting and transporting rainwater and wastewater ever since. Subsequently, effective designs and redesigns were developed; however, they collapsed as rapid urbanization and global environmental variations changed the original conditions through the increase in frequency and magnitude of urban flooding in many regions of the world [8].

Certainly, the installation and extension of the diameter in pipes or the hydraulic area in channels have speeded up the evacuation and final disposition of the surface runoff. Similarly, new trends in integrated water resource management, under the sustainable development approach, have shaped a new conceptual category called Sustainable Urban Drainage Systems (SUDS). These systems originated in the early 1970s, when the United States formulated the Clean Water Act, which allowed the Environmental Protection Agency (EPA) to start researching best practices for stormwater management called BMPs (Best Management Practices). The studies were focused on the planning, prevention and control of pollution, retention and infiltration of stormwater runoff to mitigate the collapse of the sewerage system, as well as allowing the recharge of aquifers and preventing the flooding of urban roads $[9,10]$.

SUDS are also known globally as MPC (Best Management Control), BPAs (Best Environmental Practices), LID (Low Impact Development), WSUD (Water Sensitive Urban Design), and SDUS (Sustainable Urban Drainage Systems). This broad denomination of technical solutions is part of the comprehensive sustainable management of having the potential to collect rainwater liquid [11]. In addition, it can be observed, that these water bodies end up becoming sources of water supply, contributing in some way to the Sustainable Development Goals, especially those related to environmental sustainability and the valuable liquid [12]. In particular, they are designed both to manage environmental risks from urban runoff and to contribute whenever possible to environmental improvement. Therefore, the objectives of the SUDS are to minimize development impacts on runoff quantity and quality and to maximize biodiversity opportunities [13, 14].

SUDS must be planned under a multidisciplinary approach; which means that it is necessary to incorporate the aspects of hydrology, hydraulics, geotechnics, structural calculation, environmental impact, landscaping, urban planning, among other disciplines that allow presenting alternatives that solve the urban problem of floods technically, economically, socially and environmentally [15]. In this sense, [16] considers that runoff volumes and peak flows should be reduced, regardless of the lack of hydraulic capacity of the network of conventional collectors surpassed by the urban growth overlooked in the planning phases. According to this author, the need to intervene in the conventional network in order to improve its hydraulic capacity or the fact of having to admit more frequent floods can be avoided.

The objective of this study is to assess the efficiency of implementing rainwater retention systems for the surpluses caused floods in The Tecnological Avenue in the urban center of Tepic City, in Mexico. Specifically, the surpluses that have caused floods in the Technological Avenue in the urban center of Tepic City, in Mexico. To this end, a correlational analysis was carried out with and without a project. That is, after reviewing the current conditions of the drainage system and using simulation of the water path on this main avenue, the current scenario and a prospective scenario were compared through rainwater retention systems as a flood control measure, as shown in Figure 1.

Technological Avenue is located in the southern part of the city of Tepic, in the state of Nayarit, in Mexico. Each rainy season, this area experiences floods that disrupt daily activities and affect not only urban mobility, 


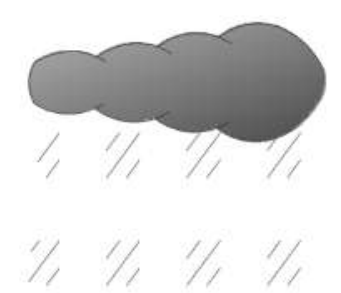

Rainwater collection

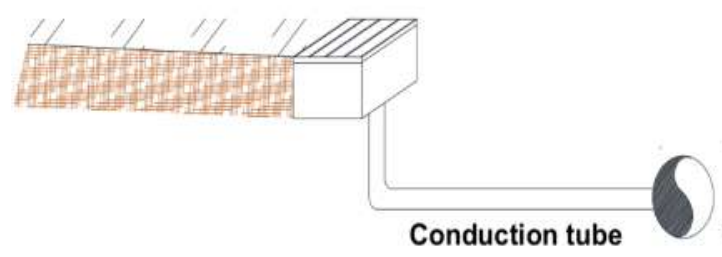

Water discharges

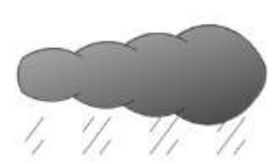

Rainwater collection

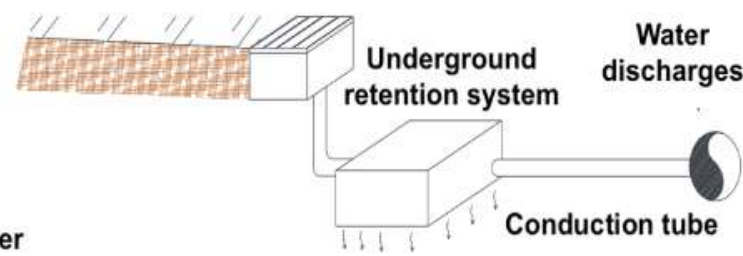

Figure 1 General diagram of a conventional system (a) and a rainwater retention system (b) Source: Own elaboration (2019)

but commerce and a portion of the adjacent university population that carries out their educational activities, are concentrated in the Tepic Institute of Technology. Approximately in a length of 350 meters and during intense rainfall of short duration that questions: al Why is the water sheet increased in this particular site?, b) Why did not this phenomenon occur earlier? and cl What corrective measures can be taken to prevent flooding?

\section{Materials and methods}

Methodologically, a documentary review, on-site visits and the conceptualization of the conceptual model Entropy-Homeostasis-Negentropy were carried out [17]. The area of study was hydrologically modelled using Geographic Information Systems (GIS) such as the Mathcad and SWWM software. In this area, there are no surface runoffs that discharge towards the receiving body (Mololoa River); therefore, the boundary of the streets and sidewalks concentrate the drains towards the lowest part of the urban axis. Based on the data obtained and hydrological and hydraulic analysis, two possible scenarios were developed: a scenario with a project and a scenario without a project. This made it possible to assess the feasibility and importance of implementing rainwater retention systems. These systems regulate the outflow volumes (inlet to the drainage network), based on the available storage and the ability of the soil to infiltrate water from urban runoff. The zone of entry of the waters to the system are the inputs generated by the volumes of surface drainage of the basin.

These inputs can be determined by the hydrologic characterization of the studied area where the water transits to a regulation zone of the system designed, and considering the input hydrograph, the output hydrograph is determined. Thus, the analysis can be determined by the hydrologic process called Channel Routing; i.e., a procedure to determine the outflow hydrograph of a dam from an input hydrograph [18]. This is based on the principle of mass conservation by means of the continuity equation. It is described using Equation 1.

$$
I-O=\frac{d V}{d t}
$$

Where:

$$
\begin{aligned}
& I=\text { Flow of entering the system } \\
& O=\text { Flow of leaving the system } \\
& \frac{d V}{d t}=\text { Variation of the volume stored in time }
\end{aligned}
$$

In the hydrographs of entry and exit before time $t_{0}$, the conditions are established and the output can be zero or equal to the cost of entering. In the time interval $t_{0}$ $<\mathrm{t}<\mathrm{t}_{1}$, the input flow is higher than the output flow; therefore, the storage volume increases. In time t1 the maximum storage, and consequently the maximum level in the system, is reached. The area between the two hydrograms for the time period $t_{0}$ and $t_{1}$ is the maximum volume stored, and consequently the volume required for storage. It can be seen in Figure 2.

The zone marked in blue shows the maximum volume of storage. The latter zone is known as system output and is determined by two factors:

a) The volume infiltrated into the permeable soil.

b) The volume spilled through the discharge hole. 


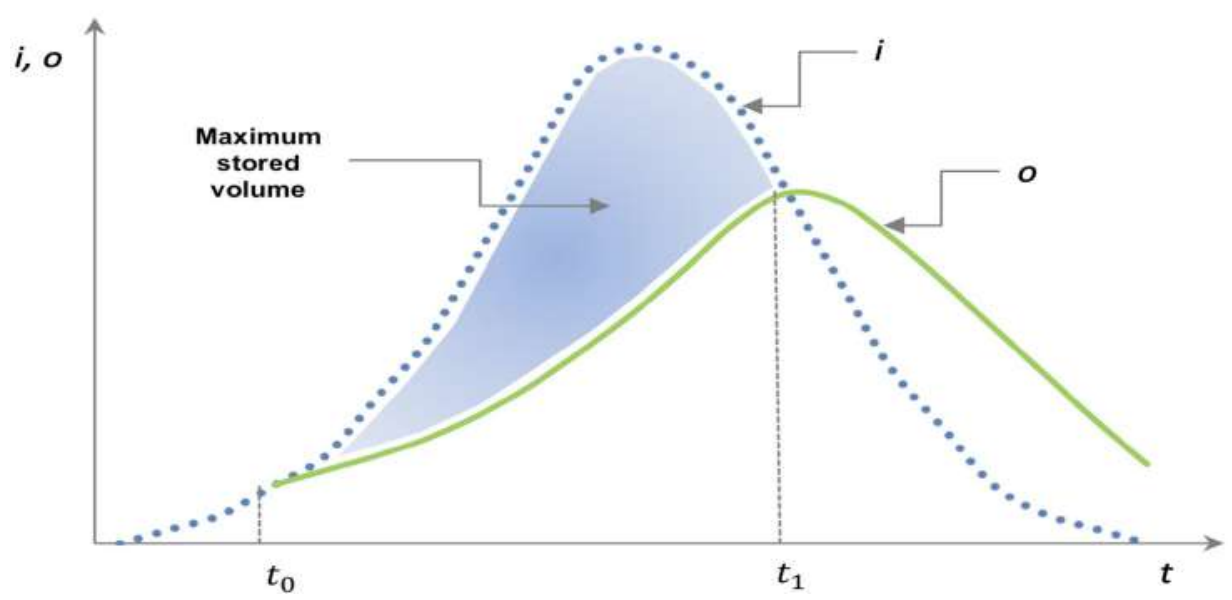

Figure 2 Entry and exit hydrograph in the Regulation Zone Source: Own elaboration (2019)

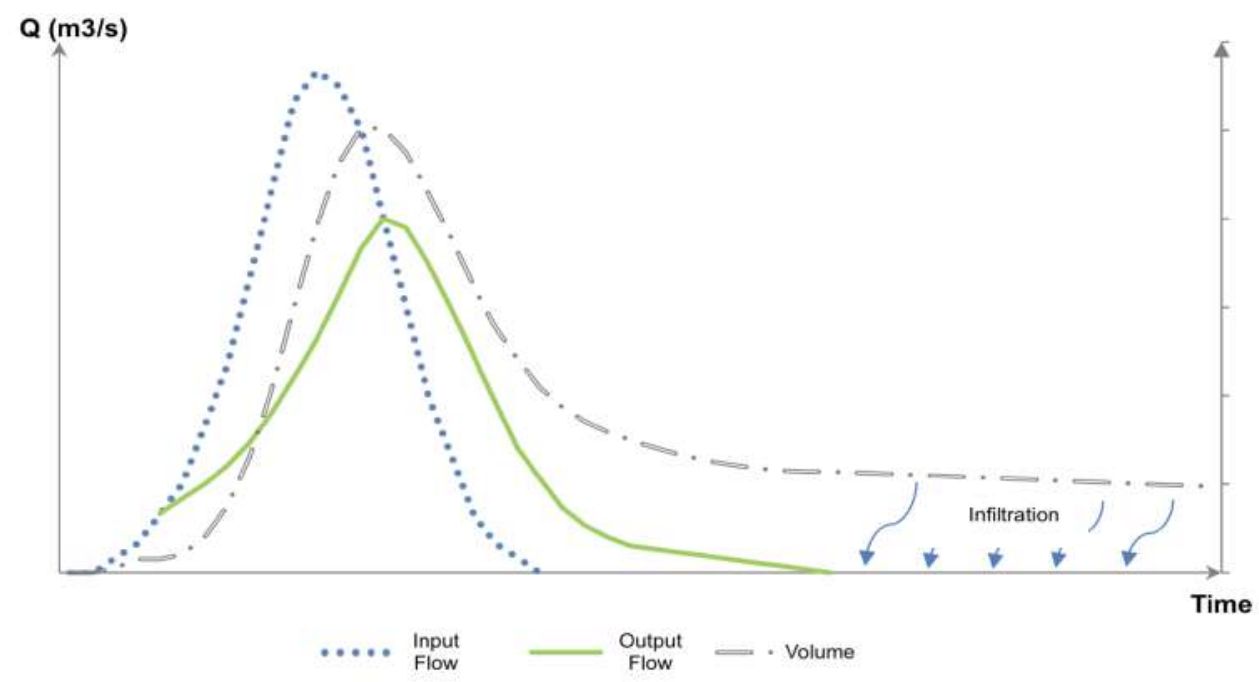

Figure 3 Operation of the retention system Source: Own elaboration (2019)

In this context, due to the small magnitude of the time interval considered in the operation of the system, the infiltrated volume can be underestimated in such analysis. However, in order for the system to fulfill the function of retaining rainwater, a certain quantity should be considered for the long-term storage of water and then naturally infiltrate it into the soil. In this way, it can be observed if the outflow is equal to zero; that is, the level of the rod in the system is lower than the crest of the spillway. This reduction in storage volume is presented by water infiltration in the field. It can be seen in Figure 3.

\section{Results}

From the logic of this qualitative EHN model, the destabilizing forces usually anthropic originate entropic scenarios in the urban system. In other words, there are forces that causally affect the city-system homeostasis. The first term of the model (entropyl has to do with the pressing forces that destabilize the morphological state of the system (homeostasis). Finally, the last term (negentropy) refers to responses capable of minimizing the levels of entropy achieved. It is shown in Table 1.

With regard to hydraulics, the design of retention alternatives determined the volumes of water in and out at different time intervals. These concentration times in minutes provided the required volume, the intensity of the rain and the surfaces of the different sub-basins. It is shown in Table 2. The values of the input volumes were determined with the rational method equation. This is described using Equation 2.

$$
V_{e}=0.00278 C i A T
$$


Table 1 EHN model for the study area Source: Own elaboration (2019)

\begin{tabular}{|c|c|c|}
\hline Entropy & Homeostasis & Negentropy \\
\hline $\begin{array}{l}\text { Replacement of natural } \\
\text { cover by rigid and } \\
\text { flexible pavements } \\
\text { (concrete and asphalt) }\end{array}$ & $\begin{array}{l}\text { Increased speed of } \\
\text { surface runoff }\end{array}$ & $\begin{array}{l}\text { Establishment of areas } \\
\text { for the natural infiltration } \\
\text { of rainwater }\end{array}$ \\
\hline $\begin{array}{l}\text { Reduction of filtration } \\
\text { rate }\end{array}$ & $\begin{array}{l}\text { Floods and increased } \\
\text { runoff speed }\end{array}$ & $\begin{array}{l}\text { Establishment of artificial } \\
\text { rainwater retention structures }\end{array}$ \\
\hline $\begin{array}{l}\text { Inability of the drainage } \\
\text { network to dislodge rainfall } \\
\text { runoff }\end{array}$ & Floods & $\begin{array}{l}\text { Complementary hydraulic } \\
\text { infrastructure, such as rainwater } \\
\text { retention structures }\end{array}$ \\
\hline $\begin{array}{l}\text { Limited public } \\
\text { policies on rainwater } \\
\text { management }\end{array}$ & $\begin{array}{l}\text { Excessive growth of } \\
\text { urban centers }\end{array}$ & $\begin{array}{l}\text { Establishment of public policies for } \\
\text { the control and management of } \\
\text { rainwater in new urban developments }\end{array}$ \\
\hline $\begin{array}{l}\text { Lack of culture for the disposal } \\
\text { of solid urban waste }\end{array}$ & $\begin{array}{l}\text { Obstruction and closure } \\
\text { of underground (pipes) or } \\
\text { surface (channels and/or } \\
\text { sewers) }\end{array}$ & $\begin{array}{l}\text { Public awareness programmes for the } \\
\text { care of public infrastructure and the } \\
\text { management and final disposal of } \\
\text { local solid waste }\end{array}$ \\
\hline
\end{tabular}

Table 2 Hydraulic analysis without retention system

\begin{tabular}{ccccccc}
\hline $\begin{array}{c}\mathbf{T} \\
\text { Minutos }\end{array}$ & $\begin{array}{c}\boldsymbol{i}_{\boldsymbol{T}}^{\mathbf{1 0}} \mathbf{\mathbf { m }} \mathbf{h r} \\
\mathbf{r}\end{array}$ & $\begin{array}{c}\text { Area } \\
\text { has }\end{array}$ & $\begin{array}{c}V_{\boldsymbol{e}} \\
\mathbf{m}^{\mathbf{3}}\end{array}$ & $\begin{array}{c}\boldsymbol{V}_{\boldsymbol{s}} \\
\mathbf{m}^{\mathbf{3}}\end{array}$ & $\begin{array}{c}\boldsymbol{V}_{\boldsymbol{e}}-\boldsymbol{V}_{\boldsymbol{s}} \\
\mathbf{m}^{\mathbf{3}}\end{array}$ & $\begin{array}{c}\left(\boldsymbol{V}_{\boldsymbol{e}}-\boldsymbol{V}_{\boldsymbol{s}}\right)_{\boldsymbol{a c}} \\
\mathbf{m}^{\mathbf{3}}\end{array}$ \\
\hline 5 & 229.53 & 0.134 & 20.69 & 20.69 & 0.00 & 0.00 \\
10 & 178.09 & 2.141 & 256.62 & 256.62 & 0.00 & 0.00 \\
15 & 147.72 & 10.841 & $1,077.80$ & $1,077.80$ & 0.00 & 0.00 \\
20 & 127.37 & 17.700 & $1,517.46$ & $1,262.40$ & 255.06 & 255.06 \\
25 & 112.66 & 32.807 & $2,487.72$ & $1,262.40$ & $1,225.32$ & $1,480.38$ \\
30 & 101.46 & 45.757 & $3,124.62$ & $1,262.40$ & $1,862.22$ & $3,342.60$ \\
35 & 92.60 & 57.70 & $3,596.04$ & $1,262.40$ & $2,333.64$ & $5,676.24$ \\
40 & 85.39 & 74.00 & $4,252.94$ & $1,262.40$ & $2,990.54$ & $8,666.78$ \\
45 & 79.40 & 99.90 & $5,338.39$ & $1,262.40$ & $4,075.99$ & $12,742.77$ \\
50 & 74.32 & 105.80 & $5,292.18$ & $1,262.40$ & $4,029.78$ & $16,772.55$ \\
55 & 69.96 & 105.80 & $4,981.53$ & $1,262.40$ & $3,719.13$ & $20,491.68$ \\
60 & 66.16 & 105.80 & $4,711.25$ & $1,262.40$ & $3,448.85$ & $23,940.53$ \\
65 & 62.83 & 105.80 & $4,473.63$ & $1,262.40$ & $3,211.23$ & $27,151.77$ \\
70 & 59.87 & 105.80 & $4,262.84$ & $1,262.40$ & $3,000.44$ & $30,152.21$ \\
75 & 57.22 & 105.80 & $4,074.37$ & $1,262.40$ & $2,811.97$ & $32,964.18$ \\
80 & 54.84 & 105.80 & $3,904.70$ & $1,262.40$ & $2,642.30$ & $35,606.48$ \\
85 & 52.68 & 105.80 & $3,751.03$ & $1,262.40$ & $2,488.63$ & $38,095.11$ \\
90 & 50.71 & 105.80 & $3,611.09$ & $1,262.40$ & $2,348.69$ & $40,443.80$ \\
95 & 48.91 & 105.80 & $3,483.04$ & $1,262.40$ & $2,220.64$ & $42,664.44$ \\
100 & 47.26 & 105.80 & $3,365.35$ & $1,262.40$ & $2,102.95$ & $44,767.40$ \\
405 & 17.96 & 105.80 & $1,279.14$ & $1,262.40$ & 16.74 & $84,884.92$ \\
410 & 17.81 & 105.80 & $1,268.12$ & $1,262.40$ & 5.72 & $84,890.64$ \\
415 & 17.66 & 105.80 & $1,257.33$ & $1,257.33$ & 0.00 & $\mathbf{8 4 , 8 9 0 . 6 4}$ \\
\hline
\end{tabular}

Source: Own elaboration (2019)

$V_{e}=$ input volumes in cubic metres $\left(\mathrm{m}^{3}\right)$.

$C=$ drainage coefficient of the basin.

$i=$ intensity and design corresponding to the duration

$\mathrm{T}$ in $\mathrm{mm} / \mathrm{hr}$.

$$
\begin{aligned}
& A=\text { basin area in hectares (has). } \\
& T=\text { storm duration in seconds (s). }
\end{aligned}
$$

Column 5 shows the output volumes (Vs), by hydraulic analysis of the current collector. The magnitudes of column 6 are the difference between the input and output 
Table 3 Hydraulic analysis with 2 parallel pipes of 60 inches

\begin{tabular}{lcccccccc}
\hline Description & $\begin{array}{c}\mathbf{D} \\
\mathbf{m}\end{array}$ & $\mathbf{S}$ & $\mathbf{n}$ & $\begin{array}{c}\mathbf{A} \\
\mathbf{m}^{\mathbf{2}}\end{array}$ & $\begin{array}{l}\mathbf{R}_{\mathbf{h}} \\
\mathbf{m}\end{array}$ & $\begin{array}{l}\mathbf{V} \\
\mathbf{m} / \mathbf{s}\end{array}$ & $\begin{array}{l}\mathbf{Q} \\
\mathbf{1 0 0 \%}\end{array}$ & $\begin{array}{l}\mathbf{Q 0 \%} \\
\mathbf{8}\end{array}$ \\
\hline $\begin{array}{l}\text { Pipe PEAD 60 } \\
\text { inches }\end{array}$ & 1.52 & 0.00165 & 0.01 & 1,815 & 0.38 & 2.13 & 3,867 & 3.78 \\
\hline $\begin{array}{l}\text { Pipe PEAD 60 } \\
\text { inches }\end{array}$ & 1.52 & 0.00165 & 0.01 & 1,815 & 0.38 & 2.13 & 3,867 & 3.78 \\
\hline
\end{tabular}

Source: Own elaboration (2019)

Table 4 Hydraulic analysis with retention system

\begin{tabular}{ccccccc}
\hline $\begin{array}{c}\mathbf{T} \\
\text { Minutos }\end{array}$ & $\begin{array}{c}\boldsymbol{i}_{\boldsymbol{T}}^{\mathbf{1 0}} \mathbf{\mathbf { m }} \mathbf{h r} \\
\mathbf{n}\end{array}$ & $\begin{array}{c}\text { Area } \\
\text { has }\end{array}$ & $\begin{array}{c}\boldsymbol{V}_{\boldsymbol{e}} \\
\mathbf{m}^{\mathbf{3}}\end{array}$ & $\begin{array}{c}\boldsymbol{V}_{\boldsymbol{s}} \\
\mathbf{m}^{\mathbf{3}}\end{array}$ & $\begin{array}{c}\boldsymbol{V}_{\boldsymbol{e}}-\boldsymbol{V}_{\boldsymbol{s}} \\
\mathbf{m}^{\mathbf{3}}\end{array}$ & $\begin{array}{c}\left(\boldsymbol{V}_{\boldsymbol{e}}-\boldsymbol{V}_{\boldsymbol{s}}\right)_{\boldsymbol{a c}} \\
\mathbf{m}^{\mathbf{3}}\end{array}$ \\
\hline 5 & 229.53 & 0.134 & 20.69 & 20.69 & 0.00 & 0.00 \\
10 & 178.09 & 2.141 & 256.62 & 256.62 & 0.00 & 0.00 \\
15 & 147.72 & 10.841 & $1,077.80$ & $1,077.80$ & 0.00 & 0.00 \\
20 & 127.37 & 17.7009 & $1,517.46$ & $1,517.46$ & 0.00 & 0.00 \\
25 & 112.66 & 32.8079 & $2,487.72$ & $2,268.00$ & 219.72 & 219.72 \\
30 & 101.46 & 45.7578 & $3,124.62$ & $2,268.00$ & 856.62 & $1,076.34$ \\
35 & 92.60 & 57.70 & $3,596.04$ & $2,268.00$ & $1,328.04$ & $2,404.38$ \\
40 & 85.39 & 74.00 & $4,252.94$ & $2,268.00$ & $1,984.94$ & $4,389.32$ \\
45 & 79.40 & 99.90 & $5,338.39$ & $2,268.00$ & $3,070.39$ & $7,459.71$ \\
50 & 74.32 & 105.80 & $5,292.18$ & $2,268.00$ & $3,024.18$ & $10,483.89$ \\
55 & 69.96 & 105.80 & $4,981.53$ & $2,268.00$ & $2,713.53$ & $13,197.42$ \\
60 & 66.16 & 105.80 & $4,711.25$ & $2,268.00$ & $2,443.25$ & $15,640.67$ \\
65 & 62.83 & 105.80 & $4,473.63$ & $2,268.00$ & $2,205.63$ & $17,846.31$ \\
70 & 59.87 & 105.80 & $4,262.84$ & $2,268.00$ & $1,994.84$ & $19,841.15$ \\
75 & 57.22 & 105.80 & $4,074.37$ & $2,268.00$ & $1,806.37$ & $21,647.52$ \\
80 & 54.84 & 105.80 & $3,904.70$ & $2,268.00$ & $1,636.70$ & $23,284.22$ \\
85 & 52.68 & 105.80 & $3,751.03$ & $2,268.00$ & $1,483.03$ & $24,767.25$ \\
90 & 50.71 & 105.80 & $3,611.09$ & $2,268.00$ & $1,343.09$ & $26,110.34$ \\
95 & 48.91 & 105.80 & $3,483.04$ & $2,268.00$ & $1,215.04$ & $27,325.38$ \\
100 & 47.26 & 105.80 & $3,365.35$ & $2,268.00$ & $1,097.35$ & $28,422.74$ \\
170 & 32.93 & 105.80 & $2,344.82$ & $2,268.00$ & 76.82 & $35,113.25$ \\
175 & 32.28 & 105.80 & $2,298.42$ & $2,268.00$ & 30.42 & $35,143.66$ \\
180 & 31.66 & 105.80 & $2,254.15$ & $2,254.15$ & 0.00 & $35,143.66$ \\
\hline
\end{tabular}

Source: Own elaboration (2019)

volumes. Finally, column 7 evaluated the required volume of the system using the maximum difference found between Ve and Vs [18-20]. Likewise, according to the results of Table 2, the required volume without project is $84,890.64 \mathrm{~m}^{3}$. In this sense, storing a volume in the order of $85,000 \mathrm{~m}^{3}$ requires considerably wide spaces, through a rehabilitation of the collector, changing the concrete pipe of 30 to 60 inches high density polyethylene pipe (PEAD). It is shown in Table 3.

In the scenario with project, the implementation of the retention system results in a storage volume of $35,143.66 \mathrm{~m}^{3}$. It is shown in Table 4. This indicates that it is 2.4 times lower than required if the current conditions of water discharge through the pipeline system are maintained.

The results show that the optimal geometry for the drain is a rectangular structure 0.80 meters high and 1.50 meters long. These dimensions provide a maximum discharge of $3.78 \mathrm{~m}^{3} / \mathrm{s}$, corresponding to a water level height of 3.21 meters. In this sense, under these characteristics and considering the backwater caused by the discharge structure, the system requires a geometry that can store up to a volume of $49,586.28 \mathrm{~m}^{3}$ This can be seen in Figure 4.

The meteorological characteristics of the basin in the increasing design and hydraulic behavior of the system determine its functioning; that is, the runoff behavior in the basin, the response of the outflow collector and the 


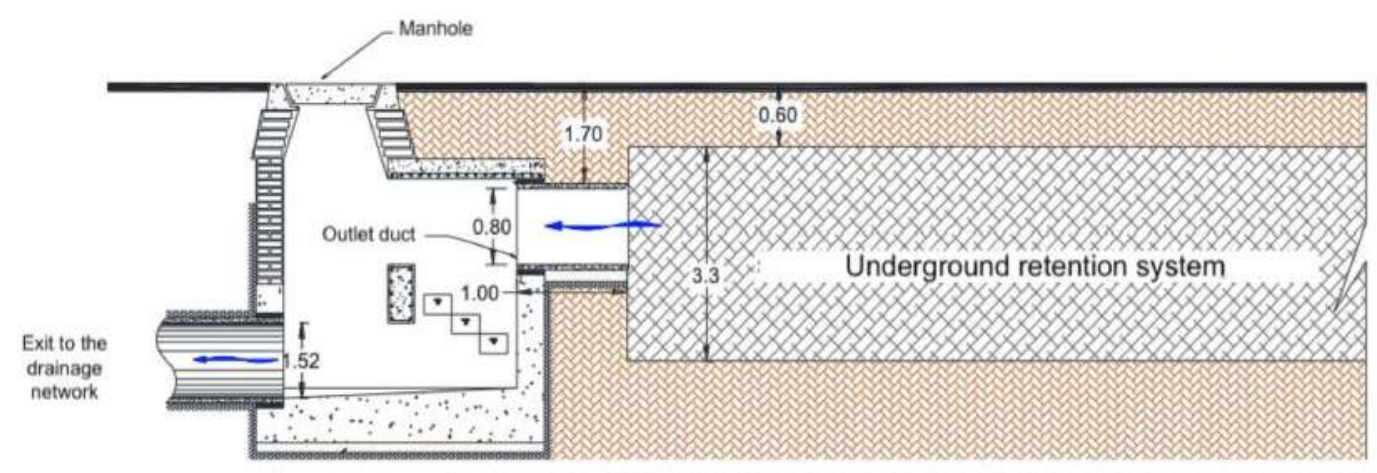

Figure $\mathbf{4}$ Optimal configuration of the retention system Source: Own elaboration (2019)

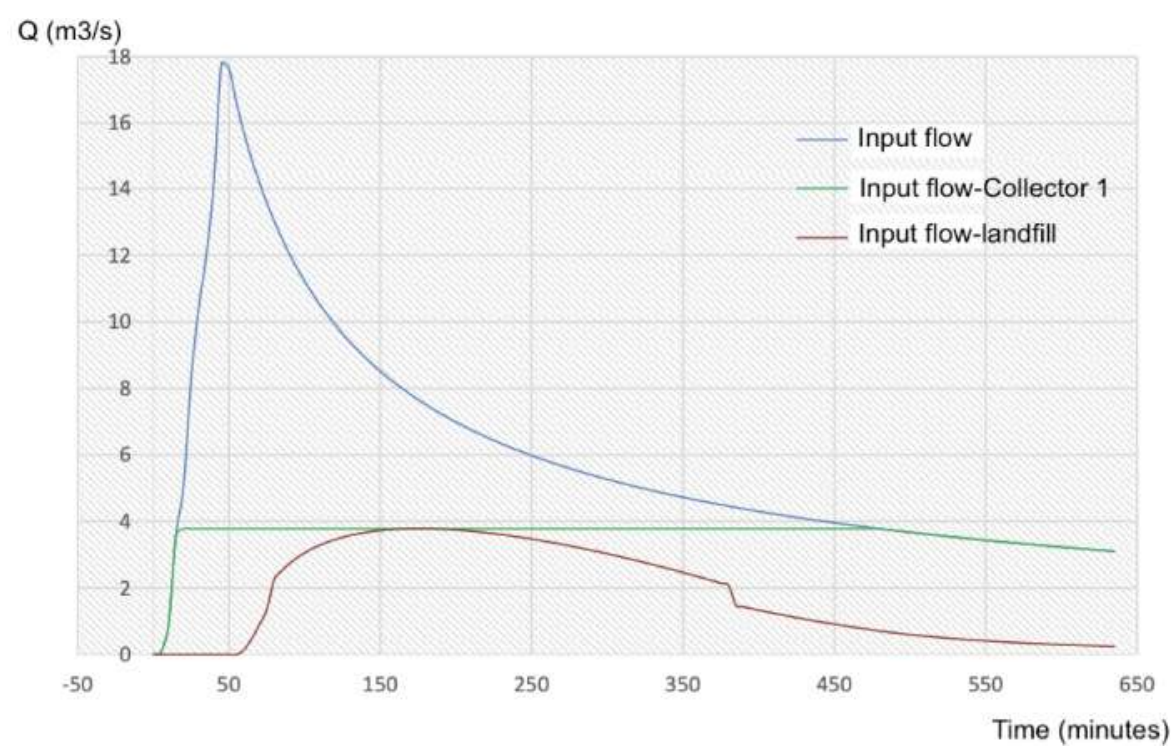

Figure 5 Flow behavior in the retention system Source: Own elaboration (2019)

flow discharged by the system towards the outflow. This can be seen in Figure 5.

Depending on the above, the general hydrograph of the retention system of the sample that, for a time $t$ $=20$ minutes, the collector has reached its maximum conductive capacity; that is, this is where the storage begins. Meanwhile, for a time $t=60$ minutes, the water level in the system has exceeded the crest level of the pourer, or the emergency spillway begins to operate. Also, for a period of time between $80<t<380$ the storage level is higher than the upper edge of the orifice and the discharge structure works like a drowned orifice. Specifically, for a time $\mathrm{t}=175$ minutes the maximum discharge flow is presented. In this sense, once the water level in the system has decreased and the flow into the system has ceased, the infiltration stage begins. It can be seen in Figure 6.
To determine the infiltration time of the volume stored in the system, it is necessary to use the Darcy equation. It is described using Equation 3.

$$
Q=K i A
$$

The value of hydraulic conductivity $(K)$ is obtained according to the prevailing soil type in the area. Generally, the soil type that predominates in the area is a clay with low organic content, whose hydraulic conductivity values are between $1 \times 10^{-4}<K<1 \times 10^{-2}$. For this particular investigation, the value of $K$ is $1 \times 10^{-4}$ $\mathrm{cm} / \mathrm{s}\left(1 \times 10^{-6} \mathrm{~m} / \mathrm{s}\right)$. In this sense, the magnitude of the hydraulic gradient $(i)$ in Equation 3 was defined as the value of the load loss between two points and the length of the flow where this loss occurs; in this case, $(i)$ is equal to the unit.

The area of the soil section is determined on the basis 


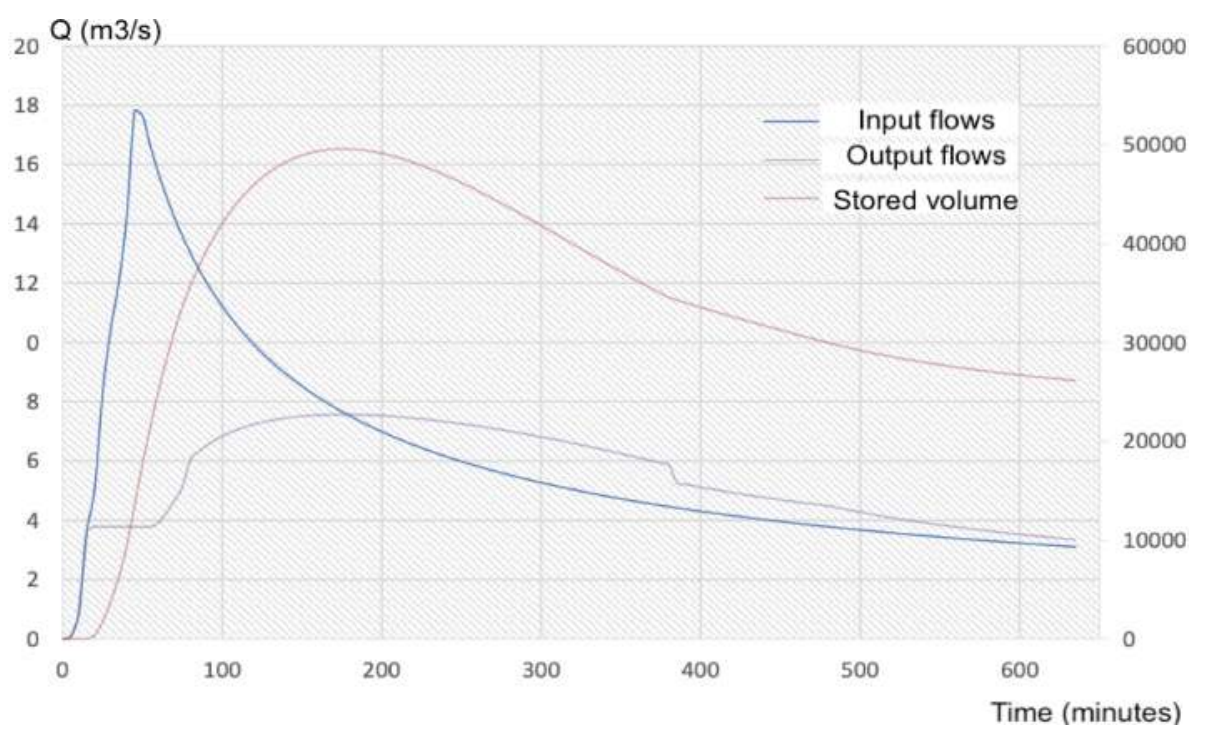

Figure 6 General hydrograph of the proposed detention-retention system Source: Own elaboration (2019)

of the water surface in contact; for this case, the surface area is $15,810 \mathrm{~m}^{2}$. Hence, it is possible to determine the time required for the stored volume to be fully consumed by the permeable stratum. Substituting these values in Equation 3 the following result was obtained: $0.016 \mathrm{~m}^{3} / \mathrm{s}$.

In sum, the volume stored of magnitude $22,134 \mathrm{~m}^{3}$, would take 16.2 days to be consumed entirely by the land.

\section{Discussion}

On Technological Avenue, daily activities have been modified, mainly affecting pedestrians, motorists, local companies and students of the Tepic Technological Institute. In addition, the current development model continues with the waterproofing of suitable areas for groundwater recharge; This implies an increase in the volumes of water in the lower parts of the basin. In this context, conventional drainage systems collect runoff through drains or sewers, and are then led to a collector. There, the collector collection discharges its flows to an emitter to finally discharge the runoff into a body of water or a treatment plant. However, the collector network is usually efficient and performs total rainfall of a certain intensity, although it is designed to transport runoff from a defined area. The problem arises when the tax area that a certain collector can handle increases, even exceeding the limit of the emitter conductors, causing overflows and floods.

At first, the area of the basin was defined, the characterization of the study area, the determination of the design costs, the hydraulic analysis of the current conditions of the network (without project) and the simulation of the retention system (with project), the result of which confirmed that the floods occurring in the area are mainly caused by the insufficiency of the drainage network to dislodge excess precipitation. In addition, in the hydraulic analysis of the current conditions of the network and the simulation of the retention system, it is plausible to corroborate that flooding in the area of interest is the cause of anthropic factors related to a change in current runoff conditions, the inability of the infrastructure to dislodge the excesses, and alterations caused by the urbanization itself.

Based on the above, no rainwater infiltration sites have been designated; this causes the accumulation of large volumes of water in the lower parts of the basin, exceeding the capacity of the drainage network and causing flooding. In this understanding, the hydraulic and hydrological analysis of the current conditions, agreement that the existing network of collectors has a conductive capacity of $4.32 \mathrm{~m}^{3} / \mathrm{s}$ (full pipe and in optimal operating conditions) that is, at $80 \%$ of its cross section, the network can only dislodge a flow of $4.20 \mathrm{~m}^{3} / \mathrm{s}$; that is, less than the flow required to evacuate in the study area, reason why the floods of Technological Avenue are frequently presented.

It is possible to affirm, that conventional systems are efficient to a certain extent; once the limit is exceeded, the main actions taken are to replace the drainage network with one of greater capacity, which generates large investments and causes a cycle where, once the drainage network has been overcome due to growth, the same phenomena occur again in urban areas. These actions cause the natural environment's ability to recharge aquifers and maintain soil moisture to be wasted, altering 
the path water takes through the hydrological cycle.

\section{Conclusions}

The appearance of this type of meteorological phenomena causes damage to neighboring structures year after year and considerable material damage. In fact, the lack of adequate public policies to achieve sustainable urban development has proportionally increased urban entropy. The floods associated with rain considered within the parameters established in local regulations for the design of drainage systems are a clear example of this existing systemic disorder.

The frequent floods in rainy season on the Technological Avenue of Tepic has been a constant concern of the local authorities who have tried to mitigate this problem without any success through the increase of the hydraulic area of the collectors. This strategy has not been sufficient, due to the lack of capacity to dislodge all the runoff and, what is more, the conditions are not created to induce the natural process of infiltration of water into the ground. The urban population plays a decisive role in the proper functioning of drainage systems, avoiding the dumping and deposition of municipal solid waste that obstructs the normal functioning of the different components of the drainage system. These wastes are dragged into rainwater runoff from catchment areas and obstruct and reduce cross section.

Flood control, peak flow mitigation and subsurface water infiltration are major factors in the functioning of the rainwater system in urban centers. Thus, where no surface land is available, or where the conditions of the environment do not permit an open pit infrastructure, these tanks must be built underground (storm tanks) [21]. Indeed, it is necessary to carry out explorations that provide a greater amount of data on the soil characteristics where the system will be developed, as well as a delimitation of the basin through a detailed topography of the site and possible deviations from runoff. Likewise, the determination of the hydrological and hydraulic results to be considered in the existing collection structures becomes a priority.

\section{Declaration of competing interest}

We declare that we have no significant competing interests including financial or non-financial, professional, or personal interests interfering with the full and objective presentation of the research described in this manuscript.

\section{Acknowledgements}

The authors acknowledge the support of the Autonomous University of Guadalajara, the University of Guadalajara and the Autonomous University of Nayarit in Mexico, and the Francisco José de Caldas University in Colombia.

\section{References}

[1] M. A. Salas and M. Jiménez. (2004, Oct.) Inundaciones. CENAPRED. Ciudad de México, México. [Online]. Available: https://bit.ly/ 2XhMLOL

[2] D. Rojas and M. G. González, "Incertidumbre en los modelos hidrológicos y planeación de obras hidráulicas en México," Ingeniería Hidráulica y Ambiental, vol. 36, no. 2, pp. 69-83, May 2015.

[3] J. Acosta, "Las inundaciones en la Argentina," in Inundaciones en el Area Metropolitana de Buenos Aires, A. Kreimer, D. Kullock, and J. B. Valdes, Eds. Washington, USA: World Bank, 2000.

[4] A. Maskrey, Los desastres no son naturales. Panama City, Republic of Panama: La Red, 1993.

[5] N. Prudkin and D. D. Pietri, "Las inundaciones en el AMBA: Análisis ecológico," in Inundaciones en el Area Metropolitana de Buenos Aires, A. Kreimer, D. Kullock, and J. B. Valdes, Eds. Washington, USA: World Bank, 2000, pp. 108-122.

[6] D. F. Campos, Introducción a la hidrología urbana, 1st ed., San Luis Potosí, México, 2010.

[7] A. Trapote and H. Fernández. (2016, Nov.) Técnicas de drenaje urbano sostenible. Instituto Universitario del Agua y de las Ciencias Ambientales. Alicante, España. [Online]. Available: https: //bit.ly/2zQx0X5

[8] Q. Zhou, "A review of sustainable urban drainage systems considering the climate change and urbanization impacts," Water, vol. 6, no. 4, April 2014. [Online]. Available: https: //doi.org/10.3390/w6040976

[9] Preliminary data summary of urban storm water best management practices. Washington DC, EEUU: Environmental Protection Agency, 1999.

[10] D. Castro, J. Rodriguez, J. Hernandez, and F. Ballester, "Sistemas urbanos de drenaje sostenible (SUDS)," Interciencia, vol. 30, no. 5, pp. 255-260, May 2005.

[11] E. D. Cubides and G. E. Santos, "Control de escorrentías urbanas mediante sistemas urbanos de drenaje sostenible (SUDS): Pozos/zanjas de infiltración," Entre Ciencia e Ingeniería, vol. 12, no. 24, December 2018. [Online]. Available: https: //doi.org/10.31908/19098367.3813

[12] C. O. Martínez, "Sistemas urbanos de drenaje sostenible SUDS: Infraestructura hidráulica urbana para el control y aprovechamiento del agua de lluvia," Undergraduate, Universidad Nacional Autónoma de México, Ciudad de México, México, 2015.

[13] The SuDS manual, CIRIA, London, England, 2007.

[14] M. P. Molina, L. Gutiérrez, and J. Salazar, "Sistemas urbanos de drenaje sostenible SUDS para el plan de ordenamiento zonal norte POZN," Secretaría Distrital de Ambiente, Bogotá, Colombia, Tech. Rep., Dec. 2011.

[15] S. Perales and I. A. Doménech, "Los sistemas urbanos de drenaje sostenible: una alternativa a la gestión del agua de lluvia," in IX Simposio de Hidrología Elche, Alicante, España, 2008, pp. 1-15.

[16] E. D. Cubides, "Control de escorrentías urbanas mediante pozos de infiltración: Aplicación práctica a un tramo del colector de aguas lluvias de la localidad de Fontibón Bogotá D.C." M.S. thesis, Escuela Colombiana de Ingeniería Julio Garavito, Bogotá, Colombia, 2016.

[17] M. G. González, "Entropy and negentropy of private electric vehicles in urban systems: Homeostasis of mobility in México," DYNA, vol. 85, no. 206, July 2018. [Online]. Available: https: //doi.org/10.15446/dyna.v85n206.72509 
[18] F. J. Aparicio, Fundamentos de hidrología de superficie. Ciudad de México, México: Limusa, 2010.

[19] G. Sotelo, Hidráulica de canales. Ciudad de México, México: Universidad Nacional Autónoma de México, 2002.

[20] A. Rocha, Hidráulica de tuberías y canales, 1st ed. Lima, Perú:
Universidad Nacional de Ingeniería, 2007.

[21] (2014, Feb.) Criterios y lineamientos técnicos para factibilidades en la A.M.G. SIAPA. Guadalajara, México. [Online]. Available: https://bit.ly/2zQgpCN 